\section{Pengembangan Bahan Ajar Sistem Peredaran Darah Manusia Berbasis Flipbook untuk Meningkatkan Kesadaran Metakognitif Siswa SMA Negeri 3 Makassar}

\author{
Syamsul Bahri HS \\ Adnan \\ Irma Suryani Idris
}

\section{Biology Teaching and Learning}

\author{
p-ISSN 2621 - 5527 \\ e-ISSN 2621 - 5535
}

Abstract. The research model used is Research and Development ( $R$ \& D) which aims to produce flipbook-based electronic teaching materials that are integrated with valid curriculum and content standards. The subjects of this study were 2 persons biology teacher, and thirty-one students in class XI SMA 3 Makassar. This research was carried out by using the modification of the ADDIE development model which consisted of the stages of Analyze, Design, Dvevelopment

Implementation, and Evaluation. The data collected is data on the results of the

flipbook-based electronic teaching

Abstract. The research model used is Research and Development ( $R \& D)$ which aims to produce flipbook-based electronic teaching materials that are integrated with valid curriculum and content standards. The subjects of this study were 2 persons biology teacher, and thirty-one students in class XI SMA 3 Makassar. This research was carried out by using the modification of the ADDIE development model which consisted of the stages of Analyze, Design, Dvevelopment, Implementation, and Evaluation. The data collected is data on the results of the flipbook-based electronic teaching material validation obtained from media and material expert validation questionnaires, the practicality obtained from the questionnaire tested through students and teachers, and the results of effectiveness obtained from the metacognitive awareness questionnaire and test results filled by students of class XI MIA 1 SMA Negeri 3 Makassar. Data obtained from the results of the study were analyzed using descriptive statistical analysis. Flipbook-based electronic teaching materials. developed has several components such as learning material, animation and learning videos, pictures, practice questions, and evaluation questions. The results of the study show that the average value of the total validity of flipbook-based electronic teaching materials as a whole is in the very valid category (4.59). The overall student response is in a very practical category (4.14). Teacher response is in a very practical category (4.28). The overall metacognition awareness of students is in the good category (3.97). Based on the results of this study, it can be concluded that the flipbook-based electronic teaching material for class XI high school studied has a high level of validity.

Keywords: learning materials, e-books, metacognitive, development.

\section{Pendahuluan}

Pendidikan merupakan salah satu indikator dan syarat penting untuk berkembangnya sebuah negara. Abad 21 dikenal sebagai era globalisasi dan teknologi informasi komunikasi (TIK). Perkembangan teknologi informasi dan komunikasi menawarkan hal baru dalam sistem pendidikan, terutama dalam aktivitas pembelajaran. Hal yang paling menonjol dalam pelaksanaan pembelajaran adalah pemanfaatan TIK mulai dari penggunaannya sebagai alat/media pembelajaran hingga sebagai sumber belajar. Untuk mewujudkan proses pembelajaran yang lebih bermakna dengan hasil belajar yang optimal, maka pendidik harus kreatif dan inovatif dalam mengembangkan media/sumber belajar. Menurut hasil survei yang dilakukan oleh National Literacy Trust's pada tahun 2012 dengan jumlah sampel pembaca di material validation obtained from media and material expert validation questionnaires, the practicality obtained

from the questionnaire tested through students and teachers, and the results of effectiveness obtained from the metacognitive awareness questionnaire and test results filled by students of class

XI MIA 1 SMA Negeri 3 Makassar. Data

obtained from the results of the study were analyzed using descriptive

statistical analysis. Flipbook-based electronic teaching materials. developed has several components such as learning material, animation and learning videos, pictures, practice questions, and evaluation questions. The results of the study show that the average value of the total validity of flipbook-based electronic

teaching materials as a whole is in the very valid category (4.59). The overall student response is in a very practical category (4.14). Teacher response is in a very practical category (4.28). The overall metacognition awareness of students is in the good category (3.97). Based on the results of this study, it can be concluded that the flipbook-based electronic teaching material for class XI high school studied has a high level of validity. Keywords: learning materials, e-books, metacognitive, development.

Syamsul Bahri HS Universitas Negeri Makassar Indonesia

Adnan

Universitas Negeri Makassar Indonesia

Irma Suryani Idris

Universitas Negeri Makassar Indonesia 
seluruh dunia yaitu 34.910 diperoleh bahwa 52,4\% pembaca lebih menyukai membaca melalui screen dibandingkan dengan print out. Alasan utama pembaca lebih memilih e-book yaitu karena kepraktisan dan keefisienannya dalam penggunaan kertas. Selain penggunaan e-book yang penggunaannya meningkat dari 5,6\% (2010) menjadi 11,9\% (2012).

Salah satu komponen dari perangkat pembelajaran adalah bahan ajar yang wajib tersedia dalam proses pembelajaran. Kurangnya sumber belajar akan berdampak pada hasil belajar yang diperoleh oleh peserta didik. Tidak hanya itu, kegiatan proses belajar mengajar juga tidak akan berlangsung secara maksimal dikarenakan beberapa peserta didik memeroleh sumber belajar dan beberapa lainnya hanya berpedoman pada lembar kerja peserta didik (LKPD) yang dimiliki. Pemberlakuan kurikulum 2013 yang masih baru di sekolah-sekolah menjadi salah satu alasan kurang tersedianya sumber belajar berupa buku paket. Jumlah peserta didik dan jumlah buku yang diedarkan tidak sebanding sehingga buku paket sifatnya tidak menetap dimiliki oleh satu peserta didik melainkan dimiliki oleh tiga sampai empat peserta didik pada satu buku paket.

Selain kurangnya jumlah buku paket yang tersedia dengan jumlah peserta didik, penyajian isi buku yang disediakan tidak menarik perhatian peserta didik untuk belajar karena konten yang terlalu padat, gambar dengan ukuran kecil dan tidak berwarna serta ketebalannya sehingga peserta didik hanya menyimpan buku paket pada laci bawah meja di sekolah mereka. Hal tersebut berdampak kepada peserta didik tidak membaca kembali materi pelajaran yang telah mereka pelajari di sekolah maupun mempelajari materi yang akan diajarkan, sehingga keingintahuan peserta didik menjadi berkurang.

Pengembangan bahan ajar berbasis e-book sudah pernah dikembangkan oleh Lena Claesson di Blekinge Institute of Technology. Menurut Claesson (2014), tersedianya laboratorium yang sifatnya virtual memberikan dampak yang baik bagi siswa untuk belajar lebih banyak tentang sains. Tersedianya laboratorium virtual maka penggunaan biaya akan semakin efisien dan bahan pengajaran dapat digunakan oleh seluruh peserta didik sebab memiliki daya tarik untuk berbagai gaya belajar. Bahan ajar elektronik yang ingin dikembangkan diintegrasikan dengan laboratorium virtual sehingga dapat mengatasi adanya ketebatasan peserta didik dalam melakukan kegiatan belajar mengajar (Eckhoff, 2002).

\section{Metode Penelitian}

Jenis penelitian yang digunakan dalam penelitian ini adalah penelitian dan pengembangan atau Research and Development (R\&D). Prosedur penelitian pengembangan ini berdasarkan model pengembangan yang dipilih, yatiu model pengembangan ADDIE. Model pengembangan ADDIE terdiri atas lima tahap yaitu: 1) Analyze, 2) Design, 3) Development 4) Implementation 5) Evaluation.

\section{Tahap analisis (Analyze)}

Pada tahap ini, peneliti melakukan analisis karakter siswa, analisis materi, serta analisis bahan ajar sebelumnya. Analisis (Analyze) dilakukan pada mata pelajaran Biologi di SMA Negeri 3 Makassar yang terkhusus pada materi sistem eksresi dan pada peserta didik kelas XI IPA 1.

\section{Tahap Rancangan (Design)}

Tahapan ini peneliti mulai merancang dan menyusun materi pembelajaran yang akan dimuat dalam bahan ajar elektronik dan rancangan susunan bahan ajar elektronik. Perangkat yang digunakan dalam pembuatan media yaitu laptop, serta beberapa Software yang akan digunakan dalam membuat bahan ajar elektronik, yaitu: Sistem Operasi Windows, Microsoft office, Adobe InDesign CC 2018, Flip creator, Paint, Adobe reader. 
Pengembangan Bahan Ajar Sistem Peredaran Darah Manusia

Berbasis Flipbook untuk Meningkatkan Kesadaran

Metakognitif Siswa SMA Negeri 3 Makassar

p-ISSN 2621-5527

(hlm. 73-80)

e-ISSN 2621-5535

\section{Tahapan Pengembangan (Development)}

Tahap ini menyatukan desain materi dan desain lay out menggunakan software flip creator dan memasukkan semua gambar, video dan animasi pembelajaran yang relevan. Setelah produk awal selesai dibuat berdasarkan rancangan, selanjutnya akan dilakukan uji validitas bahan ajar untuk mengetahui tingkatan validitas produk.

a. Uji validitas

Bahan ajar yang telah dibuat berdasarkan rancangan sebelumnya, kemudian dinilai oleh beberapa validator ahli, hal ini dilakukan untuk memperoleh saran dari validator ahli mengenai kekurangan dari media yang telah dibuat dan sekaligus memberikan nilai validitas dari produk yang di uji. Jika media yang telah dibuat belum memenuhi standar validitas maka akan dilakukan revisi pada media berdasarkan saran yang diberikan oleh validator hingga mencapai standar validitas.

\section{Tahap Iimplementasi (Implementation)}

Setelah bahan ajar elektronik telah memenuhi standar atau syarat validitas, selanjutnya akan diimplementasikan di SMA Negeri 3 kelas XI IPA 1 untuk dilakukan uji coba produk guna mengetahui kepraktisan dan keefektifan media. Kepraktisan media diperoleh melalui angket respon guru dan respon peserta didik terhadap bahan ajar yang dikembangkan. Keefektifan media diperoleh melalui tes hasil belajar dan tes kesadaran metakognitif.

\section{Tahap Evaluasi (Evaluation)}

Evaluasi adalah proses untuk melihat apakah bahan ajar elektronik yang telah diimplementasikan berhasil, sesuai dengan harapan awal atau tidak. Tahapan evaluasi dilakukan setelah melihat kevalidan, keefektifan dan kepraktisan bahan ajar elektronik yang telah di terapkan dalam proses belajar mengajar secara langsung.

\section{Hasil Penelitian}

Penelitian dan pengembangan bahan ajar elektronik telah dilakukan dengan mengacu pada model pengembangan ADDIE. Pengembangan model ADDIE terdiri atas 4 tahap yaitu: 1) Analyze, 2) Design, 3) Development 4) Implementation dan 5) Evaluation. Keseluruan perosedur penelitian yang mengacu pada model pengembangan ADDIE guna menghasilkan bahan ajar elektronik berbasis flipbook yang bersifat valid, praktis, dan efektif.

\section{Tahap analisis (Analyze)}

1. Analisis karakteristik siswa

Berdasarkan observasi yang telah dilakukan peneliti, diperoleh data yang menunjukkan bahwa (a) sebanyak 91,66\% siswa setuju bahwa setiap siswa wajib memiliki bahan ajar. Sebanyak $86,11 \%$ siswa setuju bahwa penggunaan buku paket dapat memudahkan pembelajaran di dalam kelas.

2. Analisis materi

Berdasarkan observasi yang telah dilakukan peneliti, diperoleh data yang menunjukkan bahwa (a) Sebanyak 27.78\% siswa menganggap materi bahan ajar tidak mudah dipahami, (b) sebanyak 38.89\% siswa menganggap kegiatan latihan belum sesuai dengan materi yang disajikan (c) Sebanyak 22,23\% siswa menganggap materi belum sesuai dengan standar kompetensi (d) $25 \%$ siswa menganggap bahwa terdapat miskonsepsi pada materi bahan ajar.

3. Analisis bahan ajar sebelumnya 
Berdasarkan observasi yang telah dilakukan peneliti, diperoleh data yang menunjukkan bahwa (a) 55,56\% siswa menganggap bahwa bahan ajar belum menampilkan gambar dan fitur tambahan untuk memudahkan pemahaman siswa (b) Sebanyak 52,88 siswa menganggap bahwa bahan ajar belum memiliki variasi kegiatan latihan (c) sebanyak $47.33 \%$ siswa menganggap bahwa bahan ajar belum mampu meningkatkan motivasi belajar siswa (d) sebanyak 44,45\% siswa menganggap bahwa bahan ajar belum mampu memunculkan rasa ingin tahu siswa (e) sebanyak 69,45\% siswa menganggap bahwa bahan ajar belum mampu meningkatkan rasa percaya diri siswa (f) sebanyak 50\% siswa menganggap bahwa bahan ajar belum relevan dengan kehidupan sehari-hari.

\section{Tahap perancangan (Design)}

Design (perancangan) adalah tahap di mana peneliti membuat spesifikasi mengenai arsitektur program, gaya, tampilan dan kebutuhan bahan untuk program serta materi yang akan digunakan dalam mengembangkan bahan ajar. Pada tahap ini, ada dua hasil desain, yaitu desain materi dan desain layout.

\section{Tahap pengembangan (Development)}

Setelah merancang desain bahan ajar elektronik, tahap selanjutnya yaitu pembuatan bahan ajar elektronik dengan memadukan desain materi dan desain lay out di dalam software flip creator dan menambahkan gambar, video dan animasi pembelajaran yang relevan dan sesuai dengan yang direncanakan. Setelah bahan ajar elektronik selesai maka dilakukan uji validitas bahan ajar elektronik.

1. Kevalidan bahan ajar elektronik

Hasil analisis nilai validitas bahan ajar elektronik, dapat dilihat pada tabel 1 dan tabel 2 .

Tabel 1. Hasil Uji Validitas Bahan Ajar Elektronik

\begin{tabular}{|c|c|c|c|c|c|}
\hline \multirow[t]{2}{*}{ No } & \multirow[t]{2}{*}{ Aspek Penilaian } & \multicolumn{2}{|c|}{ Rata-rata Skor } & \multirow[t]{2}{*}{ Va } & \multirow[t]{2}{*}{ Ket } \\
\hline & & Va1 & Va2 & & \\
\hline 1 & Kesesuaian Ki dan KD & 4 & 4.5 & 4.5 & SV \\
\hline 2 & Keakuratan & 4 & 4 & 4 & $\mathrm{~V}$ \\
\hline 3 & Pendukung materi & 4.75 & 5 & 4.88 & SV \\
\hline 4 & Teknik penyajian & 4.33 & 4.67 & 4.50 & SV \\
\hline 5 & Penyajian pembelajaran & 5 & 4.67 & 4.83 & SV \\
\hline 6 & Kelengkapan penyajian & 4.5 & 5 & 4.75 & SV \\
\hline 7 & Kesesuaian dengan siswa & 4 & 4 & 4 & $\mathrm{~V}$ \\
\hline 8 & Komunikatif & 5 & 5 & 5 & SV \\
\hline 9 & Keruntutan gagasan & 5 & 5 & 5 & SV \\
\hline 10 & Tata letak bahan ajar & 4.67 & 4.67 & 4.67 & SV \\
\hline \multicolumn{4}{|c|}{ Rata-rata } & 4.59 & $\mathrm{SV}$ \\
\hline
\end{tabular}

Berdasarakan Tabel 1, ditemukan bahwa bahan ajar elektronik berbasis flipbook yang telah dikembangkan secara umum memiliki nilai rata-rata sebesar 4,51. Berdasarkan kriteria penilaian pada nilai rata-rata $4.5 \leq \mathrm{Va}<5$ termasuk kategori sangat valid. 
Pengembangan Bahan Ajar Sistem Peredaran Darah Manusia

Berbasis Flipbook untuk Meningkatkan Kesadaran

Metakognitif Siswa SMA Negeri 3 Makassar

p-ISSN 2621-5527

(hlm. 73-80)

e-ISSN 2621-5535

\section{Tahap implementasi (Implementation)}

Tahap implementasi merupakan langkah nyata penerapan bahan ajar biologi elektronik yang sedang dikembangkan. Pada tahap ini, bahan ajar elektronik biologi berbasis flipbook yang telah divalidasi pada tahap development akan di uji coba dalam proses belajar mengajar di dalam kelas lalu setelah itu akan di tinjau aspek kepraktisan oleh guru dan siswa yang menggunakan bahan ajar elektronik biologi berbasis flipbook. Selanjutnya aspek lain yang akan di tinjau ialah keefektifan yang dilihat dari hasil belajar siswa berupa tes hasil belajar dan tes kesadaran metakognitif dalam bentuk pengisian angket.

1. Kepraktisan bahan ajar elektronik

a. Respon siswa

Respon siswa diambil dengan menggunakan angket respon siswa. Jumlah siswa yang merespon sebanyak 36 orang. Dari 20 item respon siswa, sebanyak 17 (85\%) direspon sangat baik oleh siswa meliputi: (i) Isi e-book menarik, (ii) Bahasa yang digunakan mudah dipahami, (iii) Gambar di e-book terbaca dengan baik, (iv) Gambar di $e$-book sesuai dengan teks, (v), Gambar di $e$-book membantu pemahaman saya, (vi) Video di $e$-book terbaca dengan baik, (vii) Video di $e$-book sesuai dengan teks, (viii) Video di e-book membantu pemahaman saya, (ix) Animasi di $e$-book terbaca dengan baik, (x) Animasi di e-book sesuai dengan teks, (xi) Animasi di $e$-book membantu pemahaman saya, (xii) Instruksi dalam e-book jelas dan terarah, (xiv) Tugas di e-book mengarahkan saya untuk belajar, (xv) E-book membuat saya aktif belajar, (xvi) E-book membuat pemahaman saya lebih meningkat terhadap materi biologi (vii) E-book membantu saya mengonstruksi pengetahuan. Sebanyak 3 siswa (15\%) direspon dengan baik. Tugas di $e$ book menantang saya untuk berpikir, penugasan di e-book terstruktur, dan E-book menantang saya untuk menerapkan berbagai strategi belajar direspon baik oleh siswa.

Hasil respon menunjukkan nilai rata-rata respon siswa diangka 4.14. Sebanyak $24(66,67 \%)$ siswa memberikan respon yang sangat baik terhadap bahan ajar biologi elektronik dan sebanyak $12(33,37 \%)$ siswa memberikan respon yang baik terhadap bahan ajar biologi elektronik. Dengan demikian, jika ditinjau dari pengkategorian kepraktisan produk, nilai 4.14 berada pada level $4 \leq \mathrm{PR} \leq 5$ yaitu sangat praktis.

b. Respon guru

Respon guru diambil dengan menggunakan angket respon guru. Jumlah guru yang merespon sebanyak 1 orang. Hasil respon menunjukkan nilai rata-rata respon di angka 4.28. Jika ditinjau dari pengkategorian kepraktisan produk, nilai 4.2 berada pada level $4 \leq \mathrm{PR} \leq 5$ yaitu sangat praktis.

2. Keefektifan bahan ajar elektronik

Uji keefektifan merupakan kegiatan pengambilan data untuk menilai keefektifan produk yang telah dikembangkan, dimana dalam hal ini adalah bahan ajar biologi elektronik berbasis flipbook.

Uji keefektifan dapat dilihat dari peningkatan kesadaran metakognitif siswa setelah menggunakan bahan ajar elektronik berbasis flipbook pada uji kesadaran metakognitif. Kriteria yang digunakan untuk memutuskan bahwa bahan ajar e-book dapat meningkatkan kesadaran metakognitif siswa adalah dengan menggunakan rumus gain ternormalisasi. Komponen metakognisi yang dibahas dalam penelitian ini, yaitu pengetahuan tentang kognisi dan pengaturan kognisi. Kesadaran metakognitif siswa secara umum sebelum penggunaan bahan ajar elektronik berbasis flipbook sebesar 3.22 (cukup baik) sedangkan setelah penggunaan bahan ajar elektronik berbasis flipbook sebesar 4.07 (baik)

Rata-rata gain ternormalisasi $<$ g $>$ untuk kesadaran metakognisi adalah 0,475 . Bila merujuk pada indeks gain (Hake, 1999), maka pembelajaran menggunakan bahan ajar elektronik berbasis flipbook dapat meningkatkan kesadaran metakognisi siswa, walaupun peningkatan tersebut termasuk pada kategori sedang $(0,70 \geq \mathrm{g}>0,30=$ sedang $)$. 


\section{Tahap evaluasi (evaluation)}

Berdasarkan data yang diperoleh, hasil menunjukkan bahwa bahan ajar elektronik yang dikembangkan berhasil. Hal ini dikarenakan nilai kevalidan, kepraktisan dan keefektifan masuk ke dalam kategori berhasil. Nilai kevalidan bahan ajar elektronik adalah 4.51 dan masuk kedalam kategori sangat valid $(4.5 \leq \mathrm{Va}<5)$. Nilai kepraktisan berdasarkan respon siswa adalah 4.14 dan masuk kedalam kategori sangat praktis dan nilai kepraktisan berdasarkan respon guru adalah 4.29 dan masuk kedalam kategori sangat praktis. Nilai keefektifan berdasarkan dari hasil uji kesadaran metakognitif siswa menunjukkan gain peningkatan di angka 0.47 dan masuk kedalam kategori sedang termasuk pada kategori sedang $(0,70 \geq \mathrm{g}>0,30=$ sedang $)$.

\section{Pembahasan}

Rata-rata nilai validitas bahan ajar elektronik berbasis flipbook sebesar 4.54. Berdasarkan kriteria penilain maka bahan ajar biologi elektronik berbasis flipbook yang dikembangkan termasuk kategori sangat valid. Adapun komponen yang dinilai yaitu, (1) Kesesuaian materi dengan KI dan KD, (2) Keakuratan, (3) Pendukung materi, (4) Teknik penyajian, (5) Penyajian pembelajaran, (6) Kelengkapan penyajian, (7) Kesesuaian dengan tingkat perkembangan peserta didik, (8) Komunikatif, (9) Keruntutan dan kesatuan gagasan, (10) Tata letak.

Berdasarkan data yang diperoleh, pembelajaran dengan bahan ajar elektronik berbasis flipbook memiliki nilai kepraktisan yang baik. Hal ini diperoleh dari respon guru dan siswa. Hasil respon guru menunjukkan nilai rata-rata respon di angka 4.28 (sangat praktis) dan hasil respon siswa menunjukkan nilai rata-rata 4.14 (sangat praktis).

Jumlah siswa yang merespon sebanyak 36 orang. Dari 20 item respon siswa, sebanyak 17 (85\%) direspon sngat baik oleh siswa meliputi: (i) Isi e-book menarik, (ii) Bahasa yang digunakan mudah dipahami, (iii) Gambar di e-book terbaca dengan baik, (iv) Gambar di e-book sesuai dengan teks, (v), Gambar di e-book membantu pemahaman saya, (vi) Video di e-book terbaca dengan baik, (vii) Video di e-book sesuai dengan teks, (viii) Video di e-book membantu pemahaman saya, (ix) Animasi di e-book terbaca dengan baik, (x) Animasi di e-book sesuai dengan teks, (xi) Animasi di e-book membantu pemahaman saya, (xii) Instruksi dalam e-book jelas dan terarah, (xiv) Tugas di e-book mengarahkan saya untuk belajar, (xv) $E$-book membuat saya aktif belajar, (xvi) E-book membuat pemahaman saya lebih meningkat terhadap materi biologi (vii) E-book membantu saya mengonstruksi pengetahuan. Sebanyak 3 (15\%) direspon dengan baik oleh siswa. Tugas di e-book menantang saya untuk berpikir, penugasan di $e$-book terstruktur, dan E-book menantang saya untuk menerapkan berbagai strategi belajar direspon baik oleh siswa.

Berdasarkan data yang diperoleh, pembelajaran dengan bahan ajar elektronik berbasis flipbook dapat menunjukkan hasil belajar yang baik. Hal ini ditunjukkan berdasarkan uji hasil belajar dimana tidak ada siswa yang memperoleh nilai dalam kategori rendah. Hal ini sesuai dengan penelitian yang dilakukan dengan Norhayati \& Siew (2004) yang membuktikan bahwa penggunaan multimedia interaktif dalam pembelajaran dapat menarik minat siswa terhadap materi yang disampaikan. Munculnya minat dan motivasi siswa tersebut, berpengaruh terhadap peningkatan hasil belajar siswa jika dibanding dengan pembelajaran tanpa bantuan multimedia interaktif. Hal ini didukung dengan penelitian terdahulu oleh Mayer \& Moreno (2000) yang menyebutkan bahwa multimedia berbasis komputer yang menghadirkan gambar animasi dan kata-kata berupa narasi mempunyai interaktifitas dan efektivitas yang cukup tinggi untuk meningkatkan pemahaman siswa terhadap materi yang dipelajari.

Berdasarkan data yang diperoleh, pembelajaran dengan bahan ajar elektronik berbasis flipbook dapat meningkatkan pengetahuan metakognisi siswa. Pengalaman belajar yang 
Pengembangan Bahan Ajar Sistem Peredaran Darah Manusia

Berbasis Flipbook untuk Meningkatkan Kesadaran

Metakognitif Siswa SMA Negeri 3 Makassar

p-ISSN 2621-5527

(hlm. 73-80)

deperoleh siswa seperti penyajian materi sesuai kebutuhan tujuan pembelajaran, pemanfaat animasi dan video pembelajaran untuk lebih mengvisualkan materi biologi yang kebanyakan sifatnya abstrak dan kegiatan latihan yang terintegrasi dengan pengamatan animasi dan video dipercaya mampu meningkatkan pengetahuan metakognitif siswa.

Pengalaman belajar baru yang diberikan kepada siswa mampu meningkatkan pengetahuan metakognitif mereka, seperti pengetahuan deklaratif, pengetahuan prosedural, dan pengetahuan kondisional.

Melalui Bahan ajar elektronik berbasis flipbook siswa mampu meningkatkan pengetahuan deklaratif yang meliputi pengetahuan tentang fakta-fakta, keyakinan-keyakinan, pendapat-

pendapat, generalisasi-generalisasi, teori-teori, hipotesis-hipotesis, dan sikap-sikap mengenai diri sendiri, orang lain dan peristiwa-peristiwa di dunia.

Melalui Bahan ajar elektronik berbasis flipbook siswa mampu meningkatkan pengetahuan deklaratif yang mengacu pada "tahu berbagai hal", pengetahuan prosedural mengacu pada "mengetahui bagaimana untuk melakukan sesuatu" (Schraw \& Moshman, 1995 dalam Balcikanly, 2011) dan diharapkan pula siswa mampu meningkatkan pengetahuan kondisional yang merupakan pemahaman kapan dan mengapa menggunakan bentuk-bentuk pengetahuan deklaratif dan prosedural.

\section{Kesimpulan}

Berdasarkan data yang diperoleh, bahwa pembelajaran dengan bahan ajar elektronik berbasis flipbook dapat meningkatkan pengaturan kognisi siswa. Pengaturan kognisi yang menjadi target peneliti setelah penggunaan bahan ajar elektronik berbasis flipbook mengacu pada lima komponen: perencanaan (memilih strategi kognitif yang tepat), managemen informasi (strategi yang digunakan untuk mengelola informasi secara efisien), pemantauan (kemajuan kesadaran atau kinerja selama tugas kognitif), debugging strategy (strategi yang digunakan untuk memperbaiki kesalahan kinerja), dan evaluasi (penilaian terhadap efisiensi pembelajaran).

\section{Referensi}

Balcikanli, C. (2011). Metacognitive Awa-reness Inventory for Teachers (MAIT). Electronic Journal of Research in Educational Psychology, 9 (3), 1309-1332. http://www.investigacion-psicopedagogica.com/revista/articulos/25/espannol/ Art 25 563.pdf.

Bedel F.E. (2012). An Examination of Locus of Control, Epistemological Beliefs and Metacognitive Awareness in Preservice Early Childhood Teachers. Gaziantep, Turkey. http://www.academia.edu/ 232 9294/An Examination_of_Locus_.

Gaeta, L. M. Teruel, P. M \& Orejudo, S. (2012). Motivational, Volitional and Metacognitive Aspects of Self Regulated Learning. Electronic Journal of Research Psychology, 10 (1), 073-094.

Haruthaihanasan, T. (2010). The Effects of Experiences with Constructivist Instruction on Attitude toward Democracy among Thai College Students. Desertation, the Faculty of the Graduate School at the University of Missouri (http://www. http://gradworks.umi.com.

Hidayat, T. Habib, 0 \& Bullent, D. (2010). Assessing Metacognitive Awareness and Learning Strategies as Positive Predictors for Success in a Distance Learning Class. Journal of Social Sciences Institute, 7 (14), 123-134. 
p-ISSN 2621-5527

e-ISSN 2621-5535
Pengembangan Bahan Ajar Sistem Peredaran Darah Manusia Berbasis Flipbook untuk Meningkatkan Kesadaran Metakognitif Siswa SMA Negeri 3 Makassar

(hlm. 73-80)

Huke, R. R. (1999). Analyzing Change/ Gain Scores. Artikel (online), (http:// www.physics.indiana.edu/ sdi/AnalyzingChange-Gain.pdf.

Mayer R.E \& Moreno R. (2000). Aids to Computer-Based Multimedia Learning. Learning and instruction, 12 (2002), 107-119.

Norhayati, A.M \& Siew, P.H. (2004). Malaysian perspective: designing interactive multimedia learning environment for moral values education. Educational Technology \& Society, 7 (4), 143-152.

Schunk, D. H. (2012). Learning Theorier, An Educational Perspective. Terjemahan oleh: Hamdiah, E dan Fajar, R. 2012. Yogyakarta. Penerbit Pustaka Pelajar.

Suparno, P. (1997). Filsafat Konstruktivisme dalam Pendidikan. Yogyakarta. Penerbit Kanisius.

Tolani-Brown N, McCormac M \& Zimmermann R. (2009). An analysis of the research and impact of ICT in education in developing country contexts. Journal of Education for International Development, 4 (2), 1-12.

\begin{tabular}{|c|c|}
\hline Syamsul Bahri HS & $\begin{array}{l}\text { Jurusan Biologi, Fakultas Matematika dan Ilmu Pengetahuan Alam, } \\
\text { Universitas Negeri Makassar. } \\
\text { Email: syamsulbahrihs798@gmail.com }\end{array}$ \\
\hline Adnan & $\begin{array}{l}\text { Dr. M.S, Dosen Jurusan Biologi, Fakultas Matematika dan Ilmu } \\
\text { Pengetahuan Alam, Universitas Negeri Makassar. } \\
\text { Email: adnan unm@yahoo.co.id }\end{array}$ \\
\hline Irma Suryani Idris & $\begin{array}{l}\text { Sp. KK, M. Kes. Dosen Jurusan Biologi, Fakultas Matematika dan Ilmu } \\
\text { Pengetahuan Alam, Universitas Negeri Makassar. } \\
\text { Email: irmasuryaniidris@unm.ac.id }\end{array}$ \\
\hline
\end{tabular}

